\title{
Effect of Organics on Content and Uptake of Nutrients by Fenugreek (Trigonella foenum-graecum 1.) Grown under Organic Farming System
}

\author{
Dhara D. Lunagariya*, V.J. Zinzala and Sandip T. Patel
}

N.M. College of Agriculture, Navsari, Navsari Agricultural University, Gujarat -396450, India

\section{Keywords}

Solid organics,

Liquid organics,

Nutrient content, Uptake

\section{Article Info}

Accepted: 04 December 2018 Available Online: 10 January 2019

\section{A B S T R A C T}

A field experiment was conducted at the certified organic farm, Navsari Agricultural University, Navsari during rabi season of 2016-2017 to study the "Effect of organics on soil properties, growth, yield and quality of fenugreek (Trigonellafoenum-graecum L.) grown under organic farming system". The treatment comprising three treatment of solid organics $\left(\mathrm{S}_{0}\right.$ : Control, $\mathrm{S}_{1}$ : NADEP compost @ $5 \mathrm{t} \mathrm{ha}^{-1}$ and $\mathrm{S}_{2}$ : Vermicompost @ $2.5 \mathrm{tha}^{-1}$ ) and four treatment of liquid organics $\left(\mathrm{L}_{0}\right.$ : Control, $\mathrm{L}_{1}$ : Panchagavya @ $20 \mathrm{~L} \mathrm{ha}^{-1}, \mathrm{~L}_{2}$ : Jeevamruta@200 L ha ${ }^{-1}$ and $\mathrm{L}_{3}$ : Enriched banana pseudostemsap @ $5 \mathrm{~L} \mathrm{ha}^{-1}$ ) were evaluated in Factorial Randomized Block Design with three replication on fenugreek variety "GM-2". After harvest, significantly higher nutrient content (N, P, K, Mn and $\mathrm{Zn}$ content in seed and $\mathrm{N}, \mathrm{P}, \mathrm{K}, \mathrm{Mn}, \mathrm{Zn}$ and $\mathrm{Cu}$ content in straw) were recorded with the treatment $\mathrm{S}_{1}$ (NADEP compost @ $5 \mathrm{t} \mathrm{ha}^{-1}$ ) and it was at par with treatment $\mathrm{S}_{2}$ (Vermicompost@2.5 $\mathrm{t} \mathrm{h}^{-1}$ ) except $\mathrm{N}$ content in seed. Similarly, treatment receiving NADEP compost @ $5 \mathrm{t} \mathrm{ha}^{-1}$ recorded significantly higher macro and micronutrient uptake by fenugreek and statistically remained at par with treatment $S_{2}$ (Vermicompost @ $2.5 \mathrm{t}$ $\mathrm{ha}^{-1}$ ).Significantly higher $\mathrm{N}, \mathrm{K}$ and $\mathrm{Mn}$ content in seed and $\mathrm{N}, \mathrm{P}$ and $\mathrm{Mn}$ content in straw were recorded with the treatment $\mathrm{L}_{3}$ (enriched banana pseudo stem sap @ $5 \mathrm{~L} \mathrm{ha}^{-1}$ ) and was at par with treatment $\mathrm{L}_{1}$ in case of $\mathrm{N}$ content in seed and Mn content in straw. $\mathrm{L}_{3}$ also found at par with treatment $\mathrm{L}_{1}$ and $\mathrm{L}_{2}$ in case of $\mathrm{K}$ content in seed of fenugreek. Application of enriched banana pseudostem sap @ $5 \mathrm{~L} \mathrm{ha}^{-1}$ recorded significantly higher macro and micronutrient uptake by fenugreek and statistically remained at par with treatment $\mathrm{L}_{1}$.In case of interaction, the combined application of NADEP compost @ $5 \mathrm{t}$ ha $^{-1}$ and enriched banana pseudostem sap @ $5 \mathrm{~L} \mathrm{ha}^{-1}\left(\mathrm{~S}_{1} \mathrm{~L}_{3}\right)$ recorded significantly higher fenugreek total $\mathrm{N}, \mathrm{P}$ and $\mathrm{K}$ uptake and was found statistically at par with treatment combination $\mathrm{S}_{1} \mathrm{~L}_{1}, \mathrm{~S}_{1} \mathrm{~L}_{2}, \mathrm{~S}_{2} \mathrm{~L}_{1}, \mathrm{~S}_{2} \mathrm{~L}_{2}$ and $\mathrm{S}_{2} \mathrm{~L}_{3}$ in case of seed and straw yield, and $\mathrm{S}_{1} \mathrm{~L}_{1}, \mathrm{~S}_{2} \mathrm{~L}_{1}$ and $\mathrm{S}_{2} \mathrm{~L}_{3}$ in case of total $\mathrm{N}, \mathrm{P}$ and $\mathrm{K}$ uptake.

\section{Introduction}

Fenugreek (Trigonellafoenum-graecumL.), locally known as Methi, is a multipurpose crop grown in Northern Indian states like Rajasthan, Gujarat, Madhya Pradesh,
Maharashtra, Haryana, Punjab, Uttar Pradesh and Andhra Pradesh, during winter season. Every part of this plant is utilized as leafy vegetable, fodder and condiments (Khiriya and Singh, 2003). Its seeds are a good source of protein, vitamins, alkaloid trigonellin and 
essential oil and have an immense medicinal value particularly against digestive disorders (Bhunia et al., 2006). Seeds are used for the treatment of diabetes, dysentery, diarrhoea and rickets. Diosgenin, which is extracted from the seeds is used in synthesis of sex hormones. Its roots are endowed with mini factory to synthesize nitrogen for plant. Thus, its cultivation enriches the soil in primary nutrient. Plant nutrient reach to the root surface by mass flow, diffusion, and root interception. Microorganism play important role in make immobilized nutrient available form to the plant. Phosphate-solubilizing bacteria (PSB) species like Pseudomonas striata and Bacillus polymyxa are also reported to be beneficial in increasing the phosphorus availability in soil and thereby seed yield of pulses (Gupta, 2006). Nitrogen plays a key role in the synthesis of chlorophyll. Nitrogen is an essential constituent of compounds like amino acids, proteins, nucleic acids, prophyrin, flavin, pyridines nucleotides, enzymes, coenzymes and alkaloids which contributes to the growth of plant. The general role of phosphorus on plant metabolism is known to enhance the symbiotic nitrogen fixation.

Plant root releases siderophore, which are help to make available micronutrient to the plant by metallic bond. They have also been reported to produce siderophore, antibiotics and exogenous compounds, which directly or indirectly increase the growth of the crop (Registeri et al., 2012). Sivaprakashan (1991) reported that plant debris, farmyard manure, and compost improved crop productivity by improving nutrient status and soil tilth, besides increasing microbial activity in the soil. For sustaining soil health and productivity of soil use different organics not only reduce the dependence on chemical fertilizers but also improve the soil structure, encourage the growth and activity of beneficial organisms in the soil, alleviate the deficiency of secondary and micronutrients, and sustain higher productivity due to improved soil health (Singh et al., 2006; Tiwari, 2002). In view content and uptake of fenugreek grown under organic farming system as evident from the above cited literature, the present study was carried out to find out the organics on content and uptake by fenugreek.

\section{Materials and Methods}

A field experiment on "Effect of organics on soil properties, growth, yield and quality of fenugreek (Trigonellafoenum-graecum L.) grown under organic farming system" was carried out at Organic Farm (F block), Navsari Agricultural University, Navsari during rabi season of 2016-17. The soil had pH 7.78 and electrical conductivity $0.44 \mathrm{dSm}_{-1}$. The soil was low in organic carbon (0.79) and available nitrogen $\left(258.12 \mathrm{~kg} \mathrm{ha}^{-1}\right)$, low in available $\mathrm{P}_{2} \mathrm{O}_{5}\left(45.58 \mathrm{~kg} \mathrm{ha}^{-1}\right)$ and high in respect to available $\quad \mathrm{K}_{2} \mathrm{O} \quad\left(273.52 \quad \mathrm{~kg} \quad \mathrm{ha}^{-1}\right)$. The experiment was laid out in factorial randomized block design with three replications.

There were twelve treatment combinations consisting of three levels of solid organics $\left(\mathrm{S}_{0}\right.$ : Control, $\mathrm{S}_{1}$ : NADEP compost @ $5 \mathrm{t} \mathrm{ha}^{-1}$ and $\mathrm{S}_{2}$ : Vermicompost @ $2.5 \mathrm{t} \mathrm{ha}^{-1}$ ) and four levels of liquid organics $\left(\mathrm{L}_{0}\right.$ : Control, $\mathrm{L}_{1}$ : Panchagavya@20 L ha ${ }^{-1}, \mathrm{~L}_{2}$ : Jeevamruta@ $200 \mathrm{~L} \mathrm{ha}^{-1}, \mathrm{~L}_{3}$ : Banana pseudostem sap @ $5 \mathrm{~L}$ $\left.\mathrm{ha}^{-1}\right)$. The solid organics were applied one day before sowing and liquid organics were incorporated in soil by drenching in the basal as per treatments. It was sown manually at 30 $\mathrm{cm}$ row to row spacing keeping seed rate of 20 $\mathrm{kg} \mathrm{ha}^{-1}$. The fenugreek variety Gujarat Methi2 was sown in December during 2016-17. Standard agronomic practices were adopted for raising healthy crop. Data of growth and yield attributes were taken from 5 tagged plants. Biological and economic yields were taken from net plot. 


\section{Effect of solid organics}

Significantly higher N, P, K content and uptake by seed $\left(2.79 \%\right.$ and $\left.31.89 \mathrm{~kg} \mathrm{ha}^{-1}\right)$, $\left(0.353 \%\right.$ and $\left.4.016 \mathrm{~kg} \mathrm{ha}^{-1}\right),(1.05 \%$ and 11.91 $\left.\mathrm{kg} \mathrm{ha}^{-1}\right)$ and straw $\left(0.89 \%\right.$ and $\left.18.25 \mathrm{~kg} \mathrm{ha}^{-1}\right)$, $\left(0.142 \%\right.$ and $\left.2.93 \mathrm{~kg} \mathrm{ha}^{-1}\right),(0.453 \%$ and 9.35 $\mathrm{kg} \mathrm{ha}^{-1}$ ) were recorded under the treatment $\mathrm{S}_{1}$, but $\mathrm{N}, \mathrm{P}, \mathrm{K}$ content and uptake by seed and straw was at par with treatment $\mathrm{S}_{2}$ except $\mathrm{N}$ content in straw. The significantly highest total uptake of $\mathrm{N}, \mathrm{P}$ and $\mathrm{K}\left(50.14 \mathrm{~kg} \mathrm{ha}^{-1}, 6.94\right.$ $\mathrm{kg} \mathrm{ha}^{-1}$ and $21.26 \mathrm{~kg} \mathrm{ha}^{-1}$ was found with the application of NADEP compost @ $5 \mathrm{t} \mathrm{ha}^{-1}$ $\left(\mathrm{S}_{1}\right)$. However, significantly lowest $\mathrm{N}, \mathrm{P}, \mathrm{K}$ content and uptake in seed and straw were noted under treatment $\mathrm{S}_{0}$ (Control). The data indicated that $\mathrm{Fe}$ and $\mathrm{Cu}$ content in seed and Fe content straw in seed of fenugreek didn't show significantly by the application of different solid organics, but gave significantly higher $\mathrm{Fe}, \mathrm{Mn}, \mathrm{Zn}$ and $\mathrm{Cu}$ uptake by seed and straw. Significantly higheZrMn and $\mathrm{Zn}$ content in seed (26.58 $\mathrm{mg} \mathrm{kg}^{-1}, 20.40 \mathrm{mg} \mathrm{kg}^{-1}$ ) and $\mathrm{Mn}, \mathrm{Zn}$ and $\mathrm{Cu}$ content in straw (40.23 $\mathrm{mg} \mathrm{kg}{ }^{-1}, 18.47 \mathrm{mg} \mathrm{kg}^{-1}, 6.20 \mathrm{mg} \mathrm{kg}^{-1}$ ) were recorded under the treatment NADEP compost (a) $5 \mathrm{t} \mathrm{ha}^{-1}\left(\mathrm{~S}_{1}\right)$ which was at par with treatment $S_{2}$. However, significantly the lowest $\mathrm{Mn}, \mathrm{Zn}$ and $\mathrm{Cu}$ content and uptake by seed and straw were observed with the treatment $S_{0}$ (Control) except $\mathrm{Cu}$ content in seed. The total $\mathrm{Fe}, \mathrm{Mn}, \mathrm{Zn}$ and $\mathrm{Cu}$ uptake by fenugreek was significantly increased with the application of NADEP compost @ $5 \mathrm{t} \mathrm{ha}^{-1}$ and remained at par with the application of vermicompost @ $2.5 \mathrm{t} \mathrm{ha}^{-1}$ (340.62 $\left.\mathrm{g} \mathrm{ha}^{-1}\right)$. Significantly the lowest total uptake was observed under control. Statistically remained at par with treatment $S_{2}$. The increase in nutrient content due to addition of low $\mathrm{C}: \mathrm{N}$ ratio containing NADEP compost and vermicompost enhanced early mineralization thus increasing the availability of macro and micronutrient and minimizing the fixation of plant nutrient like phosphorus, potassium etc. These organics also helped in steady supply of balanced nutrient throughout the growth period due to improvement in soil fertility status. These findings are in general agreement with the experimental results reported by Naikwade et al., (2011), Kumar et al., (2012), Das (2014), Naikwade (2014), Dekhane et al., (2011), Jat et al., (2012), Kumar and Sharma (2014), Verma et al., (2014) and Tak et al., (2014) (Table 1).

\section{Effect of liquid organics}

Application of liquid organics were also shows significantly effect on $\mathrm{N}, \mathrm{P}, \mathrm{K}$ content and uptake by fenugreek (Table 3). The significantly higher $\mathrm{N}, \mathrm{K}$ content in seed $(2.74 \%, 1.03 \%$,$) and \mathrm{N}, \mathrm{P}$ content in straw $(0.89 \%, 0.144 \%)$, also N, P, K uptake by seed (30.32 kg ha ${ }^{-1}, 3.866 \mathrm{~kg} \mathrm{ha}^{-1}, 11.39 \mathrm{~kg} \mathrm{ha}^{-1}$ ) and by straw $\left(17.71 \mathrm{~kg} \mathrm{ha}^{-1}, 2.89 \mathrm{~kg} \mathrm{ha}^{-1}, 9.10\right.$ $\mathrm{kg} \mathrm{ha}^{-1}$ ) were recorded under the treatment $\mathrm{L}_{3}$. while $\mathrm{N}, \mathrm{K}$ content in seed, N, P content in straw and uptake by seed and straw was at par with treatment $\mathrm{L}_{1}$. However, significantly the lowest $\mathrm{N}, \mathrm{K}$ content in seed and $\mathrm{N}, \mathrm{P}$ content in straw were noted under the treatment $\mathrm{L}_{0}$ (Control). The data indicated that $\mathrm{Fe}, \mathrm{Zn}$ and $\mathrm{Cu}$ content in seed and straw of fenugreek were not influenced significantly by the application of liquid organics, but it was influenced significantly on uptake by seed and straw. The higher $\mathrm{Fe}, \mathrm{Zn}$ and $\mathrm{Cu}$ content in seed (43.06 mg kg-1, 20.36mg kg-1, $6.15 \mathrm{mg}$ $\mathrm{kg}^{-1}$ ) and straw (147.60 $\mathrm{mg} \mathrm{kg}^{-1}, 18.48 \mathrm{mg}$ $\mathrm{kg}^{-1}, 6.20 \mathrm{mg} \mathrm{kg}{ }^{-1}$ ) were found with the treatment $\mathrm{L}_{3}$. Significantly higher Mn content in seed (26.73 $\mathrm{mg} \mathrm{kg}^{-1}$ ) and straw (39.69 mg $\mathrm{kg}^{-1}$ ) were recorded under the treatment $\mathrm{L}_{3}$ which was at par with treatment $\mathrm{L}_{1}$. The application of enriched banana pseudostem sap @ $5 \mathrm{~L} \mathrm{ha}^{-1}\left(\mathrm{~L}_{3}\right)$ gave significantly higher $\mathrm{Fe}, \mathrm{Mn}, \mathrm{Zn}$ and $\mathrm{Cu}$ uptake by seed and straw and statistically at par with treatment $\mathrm{L}_{1}$. However, significantly the lowest uptake by seed and straw were noted with the treatment $\mathrm{L}_{0}$ (Control). 
Table.1 Effect of solid and liquid organics on N, P, K content and uptake by fenugreek

\begin{tabular}{|c|c|c|c|c|c|c|c|c|c|c|c|c|c|c|c|}
\hline \multirow[t]{2}{*}{ Treatment } & \multicolumn{2}{|c|}{$\begin{array}{c}\text { N Content } \\
(\%)\end{array}$} & \multicolumn{3}{|c|}{$\begin{array}{c}\text { N Uptake } \\
\left(\mathrm{kg} \mathrm{ha}^{-1}\right)\end{array}$} & \multicolumn{2}{|c|}{$\begin{array}{c}\text { P Content } \\
(\%)\end{array}$} & \multicolumn{3}{|c|}{$\begin{array}{c}\text { P Uptake } \\
\left(\mathrm{kg} \mathrm{ha}^{-1}\right)\end{array}$} & \multicolumn{2}{|c|}{$\begin{array}{c}\text { K Content } \\
(\%)\end{array}$} & \multicolumn{3}{|c|}{$\begin{array}{c}\text { K Uptake } \\
\left(\mathrm{kg} \mathrm{ha}^{-1}\right)\end{array}$} \\
\hline & Seed & Straw & Seed & Straw & Total & Seed & Straw & Seed & Straw & Total & Seed & Straw & Seed & Straw & Total \\
\hline \multicolumn{16}{|c|}{ Solid organics (S) } \\
\hline $\mathbf{S}_{0}$ & 2.31 & 0.82 & 18.25 & 11.69 & 29.94 & 0.342 & 0.127 & 2.70 & 1.82 & 4.52 & 0.94 & 0.400 & 7.44 & 5.72 & 13.16 \\
\hline $\mathbf{S}_{1}$ & 2.79 & 0.89 & 31.89 & 18.25 & 50.14 & 0.353 & 0.142 & 4.02 & 2.93 & 6.94 & 1.05 & 0.453 & 11.91 & 9.35 & 21.26 \\
\hline $\mathbf{S}_{\mathbf{2}}$ & 2.67 & 0.88 & 29.13 & 17.74 & 46.87 & 0.352 & 0.141 & 3.81 & 2.84 & 6.65 & 1.04 & 0.449 & 11.23 & 9.06 & 20.29 \\
\hline S.Em. $( \pm)$ & 0.03 & 0.005 & 0.86 & 0.42 & 1.01 & 0.002 & 0.002 & 0.107 & 0.08 & 0.13 & 0.01 & 0.008 & 0.32 & 0.31 & 0.41 \\
\hline CD at $5 \%$ & 0.09 & 0.015 & 2.51 & 1.24 & 2.96 & 0.007 & 0.005 & 0.313 & 0.23 & 0.38 & 0.03 & 0.02 & 0.93 & 0.91 & 1.20 \\
\hline \multicolumn{16}{|c|}{ Liquid organics (L) } \\
\hline $\mathbf{L}_{0}$ & 2.40 & 0.84 & 20.20 & 12.96 & 33.16 & 0.342 & 0.132 & 2.87 & 2.03 & 4.90 & 0.98 & 0.417 & 8.26 & 6.44 & 14.69 \\
\hline $\mathbf{L}_{1}$ & 2.64 & 0.87 & 28.56 & 16.99 & 45.54 & 0.351 & 0.137 & 3.75 & 2.70 & 6.45 & 1.02 & 0.439 & 10.92 & 8.66 & 19.58 \\
\hline $\mathbf{L}_{2}$ & 2.60 & 0.86 & 26.61 & 15.93 & 42.54 & 0.350 & 0.134 & 3.55 & 2.50 & 6.05 & 1.00 & 0.428 & 10.20 & 7.98 & 18.18 \\
\hline $\mathbf{L}_{3}$ & 2.74 & 0.89 & 30.32 & 17.71 & 48.03 & 0.353 & 0.144 & 3.87 & 2.89 & 6.76 & 1.03 & 0.452 & 11.39 & 9.10 & 20.49 \\
\hline S.Em. ( \pm$)$ & 0.03 & 0.006 & 0.99 & 0.49 & 1.17 & 0.003 & 0.002 & 0.123 & 0.09 & 0.15 & 0.01 & 0.009 & 0.37 & 0.36 & 0.47 \\
\hline CD at $5 \%$ & 0.10 & 0.018 & 2.90 & 1.44 & 3.42 & NS & 0.005 & 0.361 & 0.26 & 0.44 & 0.03 & NS & 1.07 & 1.05 & 1.39 \\
\hline \multicolumn{16}{|c|}{ Interaction (S X L) } \\
\hline S.Em. $( \pm)$ & 0.06 & 0.010 & 1.71 & 0.85 & 2.02 & 0.005 & 0.003 & 0.213 & 0.16 & 0.26 & 0.02 & 0.016 & 0.63 & 0.62 & 0.82 \\
\hline CD at $5 \%$ & NS & NS & NS & NS & 5.92 & NS & NS & NS & NS & 0.76 & NS & NS & NS & NS & 2.41 \\
\hline CV \% & 3.94 & 2.11 & 11.21 & 9.25 & 8.27 & 2.31 & 4.01 & 10.53 & 10.69 & 7.44 & 3.00 & 6.32 & 10.76 & 13.33 & 7.80 \\
\hline
\end{tabular}

Table.2 Interaction effect of solid and liquid organics on total N, P, K uptake by fenugreek

\begin{tabular}{|c|c|c|c|c|c|c|c|c|c|}
\hline \multirow{2}{*}{$\begin{array}{ll}\text { Liquid } & \text { Solid } \\
\text { organics } & \text { erganics }\end{array}$} & \multicolumn{3}{|c|}{ Total N uptake $\left(\mathrm{kg} \mathrm{ha}^{-1}\right)$} & \multicolumn{3}{|c|}{ Total P uptake $\left(\mathrm{kg} \mathrm{ha}^{-1}\right)$} & \multicolumn{3}{|c|}{ Total K uptake $\left(\mathrm{kg} \mathrm{ha}^{-1}\right)$} \\
\hline & $\mathbf{S}_{\mathbf{0}}$ & $\mathbf{S}_{1}$ & $\mathbf{S}_{\mathbf{2}}$ & $\mathbf{S}_{\mathbf{0}}$ & $\mathbf{S}_{1}$ & $\mathbf{S}_{\mathbf{2}}$ & $\mathbf{S}_{\mathbf{0}}$ & $\mathbf{S}_{1}$ & $\mathbf{S}_{\mathbf{2}}$ \\
\hline $\mathbf{L}_{\mathbf{0}}$ & 26.94 & 38.29 & 34.25 & 4.19 & 5.54 & 4.96 & 12.33 & 16.72 & 15.03 \\
\hline $\mathbf{L}_{1}$ & 31.04 & 53.79 & 51.80 & 4.64 & 7.42 & 7.28 & 13.51 & 22.98 & 22.25 \\
\hline $\mathbf{L}_{2}$ & 29.64 & 51.21 & 46.76 & 4.48 & 6.95 & 6.71 & 12.99 & 21.19 & 20.36 \\
\hline $\mathbf{L}_{3}$ & 32.15 & 57.27 & 54.67 & 4.77 & 7.85 & 7.65 & 13.80 & 24.14 & 23.52 \\
\hline S.Em. $( \pm)$ & \multicolumn{3}{|c|}{2.02} & \multicolumn{3}{|c|}{0.26} & \multicolumn{3}{|c|}{0.82} \\
\hline CD at $5 \%$ & \multicolumn{3}{|c|}{5.92} & \multicolumn{3}{|c|}{0.76} & \multicolumn{3}{|c|}{2.41} \\
\hline CV \% & \multicolumn{3}{|c|}{8.27} & \multicolumn{3}{|c|}{7.44} & \multicolumn{3}{|c|}{7.80} \\
\hline
\end{tabular}


Table.3 Effect of solid and liquid organics on Micronutrient content and uptake by fenugree

\begin{tabular}{|c|c|c|c|c|c|c|c|c|c|c|}
\hline \multirow[t]{2}{*}{ Treatment } & \multicolumn{2}{|c|}{ Fe Content (mg kg $\left.{ }^{-1}\right)$} & \multicolumn{3}{|c|}{ Fe Uptake ( g ha $\left.^{-1}\right)$} & \multicolumn{2}{|c|}{ Mn Content (mg kg-1) } & \multicolumn{3}{|c|}{ Mn Uptake (g ha $\left.{ }^{-1}\right)$} \\
\hline & Seed & Straw & Seed & Straw & Seed & Seed & Straw & Seed & Straw & Seed \\
\hline \multicolumn{11}{|c|}{ Solid organics (S) } \\
\hline $\mathbf{S}_{\mathbf{0}}$ & 39.72 & 142.27 & 31.22 & 203.98 & 235.20 & 25.59 & 36.93 & 20.16 & 52.90 & 73.06 \\
\hline $\mathbf{S}_{1}$ & 42.48 & 147.35 & 48.37 & 302.38 & 350.75 & 26.58 & 40.23 & 30.26 & 82.60 & 112.86 \\
\hline $\mathbf{S}_{\mathbf{2}}$ & 42.37 & 146.57 & 45.95 & 295.25 & 340.62 & 26.42 & 40.03 & 28.66 & 80.39 & 109.05 \\
\hline S.Em. $( \pm)$ & 0.88 & 2.13 & 1.33 & 7.49 & 7.46 & 0.15 & 0.17 & 0.85 & 1.86 & 3.03 \\
\hline CD at $5 \%$ & NS & NS & 3.90 & 21.96 & 21.88 & 0.45 & 0.50 & 2.50 & 5.46 & 8.90 \\
\hline \multicolumn{11}{|c|}{ Liquid organics (L) } \\
\hline $\mathbf{L}_{\mathbf{0}}$ & 40.55 & 143.30 & 34.06 & 219.76 & 253.82 & 25.84 & 38.08 & 21.67 & 58.54 & 80.21 \\
\hline $\mathbf{L}_{1}$ & 41.80 & 146.38 & 44.75 & 286.62 & 331.37 & 26.19 & 39.33 & 28.03 & 77.21 & 105.25 \\
\hline $\mathbf{L}_{2}$ & 40.69 & 144.32 & 41.20 & 266.64 & 307.84 & 26.02 & 38.89 & 26.39 & 72.20 & 98.59 \\
\hline $\mathbf{L}_{3}$ & 43.06 & 147.60 & 47.37 & 295.80 & 342.40 & 26.73 & 39.69 & 29.35 & 79.87 & 109.25 \\
\hline S.Em. ( \pm$)$ & 1.01 & 2.45 & 1.53 & 8.64 & 10.38 & 0.18 & 0.20 & 0.98 & 2.34 & 3.50 \\
\hline CD at $5 \%$ & NS & NS & 4.50 & 25.35 & 30.45 & 0.52 & 0.58 & 2.71 & 6.87 & 10.27 \\
\hline \multicolumn{11}{|c|}{ Interaction (S X L) } \\
\hline S.Em. ( \pm$)$ & 1.75 & 4.25 & 2.66 & 14.97 & 17.98 & 0.31 & 0.34 & 1.71 & 4.06 & 6.07 \\
\hline CD at $5 \%$ & NS & NS & NS & NS & NS & NS & NS & NS & NS & NS \\
\hline $\mathrm{CV} \%$ & 7.31 & 5.06 & 11.00 & 9.70 & 10.08 & 2.03 & 1.53 & 11.20 & 9.77 & 10.69 \\
\hline
\end{tabular}


Table.3 Continued

\begin{tabular}{|c|c|c|c|c|c|c|c|c|c|c|}
\hline \multirow[t]{2}{*}{ Treatment } & \multicolumn{2}{|c|}{ Zn Content (mg kg-1) } & \multicolumn{3}{|c|}{ Zn Uptake $\left(\mathrm{g} \mathrm{ha}^{-1}\right)$} & \multicolumn{2}{|c|}{ Cu Content (mg kg $\left.{ }^{-1}\right)$} & \multicolumn{3}{|c|}{ Cu Uptake (g ha $\left.{ }^{-1}\right)$} \\
\hline & Seed & Straw & Seed & Straw & Total & Seed & Straw & Seed & Straw & Tota \\
\hline \multicolumn{11}{|c|}{ Solid organics (S) } \\
\hline $\mathbf{S}_{\mathbf{0}}$ & 19.74 & 17.91 & 15.54 & 25.63 & 41.17 & 6.08 & 5.98 & 4.79 & 8.58 & 13.37 \\
\hline $\mathbf{S}_{1}$ & 20.40 & 18.47 & 23.21 & 37.89 & 61.10 & 6.15 & 6.20 & 6.99 & 12.74 & 19.74 \\
\hline $\mathbf{S}_{2}$ & 20.29 & 18.29 & 22.01 & 36.73 & 58.74 & 6.13 & 6.17 & 6.64 & 12.40 & 19.04 \\
\hline S.Em. $( \pm)$ & 0.15 & 0.11 & 0.62 & 0.94 & 1.53 & 0.04 & 0.05 & 0.19 & 0.33 & $\mathbf{0 . 5 3}$ \\
\hline CD at $5 \%$ & 0.45 & 0.32 & 1.83 & 2.75 & 4.48 & NS & 0.15 & 0.54 & 0.97 & 1.56 \\
\hline \multicolumn{11}{|c|}{ Liquid organics (L) } \\
\hline $\mathbf{L}_{\mathbf{0}}$ & 19.92 & 18.01 & 16.67 & 27.63 & 44.31 & 6.09 & 6.03 & 5.10 & 9.25 & 14.36 \\
\hline $\mathbf{L}_{1}$ & 20.24 & 18.29 & 21.68 & 35.70 & 57.38 & 6.13 & 6.16 & 6.55 & 12.07 & 18.61 \\
\hline $\mathbf{L}_{2}$ & 20.05 & 18.10 & 20.33 & 33.50 & 53.83 & 6.11 & 6.08 & 6.18 & 11.27 & 17.45 \\
\hline $\mathbf{L}_{3}$ & 20.36 & 18.48 & 22.34 & 36.82 & 59.16 & 6.15 & 6.20 & 6.74 & 12.37 & 19.11 \\
\hline S.Em. $( \pm)$ & 0.18 & 0.13 & 0.72 & 1.08 & 1.76 & 0.05 & 0.06 & 0.21 & 0.38 & 0.61 \\
\hline CD at $5 \%$ & NS & NS & 2.11 & 3.18 & 5.17 & NS & NS & 0.63 & 1.12 & 1.80 \\
\hline \multicolumn{11}{|c|}{ Interaction (S X L) } \\
\hline S.Em. $( \pm)$ & 0.31 & 0.22 & 1.25 & 1.88 & 3.05 & 0.09 & 0.10 & 0.37 & 0.66 & 1.06 \\
\hline CD at $5 \%$ & NS & NS & NS & NS & NS & NS & NS & NS & NS & NS \\
\hline CV \% & 2.63 & 2.06 & 10.65 & 9.73 & 9.86 & 2.45 & 2.95 & 10.44 & 10.17 & 10.58 \\
\hline
\end{tabular}


Total $\mathrm{Fe}, \mathrm{Mn}, \mathrm{Zn}$ and $\mathrm{Cu}$ uptake by fenugreek was significantly varied with different treatment. The treatment $\mathrm{L}_{3}$ recorded significantly higher total uptake and was at par with treatment $\mathrm{L}_{1}$. The least value of total uptake was recorded under control $\left(\mathrm{L}_{0}\right)$. Sreenivasa et al., (2010) reported the presence of many beneficial microorganisms viz., nitrogen fixers, phosphorus solubilizers, actinomycetes and fungi in panchagavya, increases the availability of nutrients and helps in absorption of these nutrients and finally increased the total uptake. These finding are in general agreement with the experimental results reported by Sathish and Paramaguru (2010), Choudhary et al., (2013), Patil and Kolambe (2013), Salunkhe et al., (2013) and Boraiah et al., (2015).

\section{Interaction effect}

The interaction of solid and liquid organics on $\mathrm{N}, \mathrm{P}$ and $\mathrm{K}$ content and uptake by seed and straw of fenugreek were found to be nonsignificant, but total $\mathrm{N}, \mathrm{P}$ and $\mathrm{K}$ uptake by fenugreek was found to be significant (Table $3)$. The combined application of NADEP compost @ $5 \mathrm{t} \mathrm{ha}^{-1}+$ enriched banana pseudo stem sap @ $5 \mathrm{~L} \mathrm{ha}^{-1}\left(\mathrm{~S}_{1} \mathrm{~L}_{3}\right)$ produced significantly higher total $\mathrm{N}$ uptake $(57.27 \mathrm{~kg}$ $\left.\mathrm{ha}^{-1}\right)$, P uptake (7.85 $\mathrm{kg} \mathrm{ha}^{-1}$ ) and $\mathrm{K}$ uptake $\left(24.14 \mathrm{~kg} \mathrm{ha}^{-1}\right)$ and statistically remained at par with treatment combination $S_{1} L_{1}, S_{2} L_{1}$ and $\mathrm{S}_{2} \mathrm{~L}_{3}$. The significantly lower total $\mathrm{N}, \mathrm{P}$ and $\mathrm{K}$ uptake by fenugreek was noted under treatment $\mathrm{S}_{0} \mathrm{~L}_{0}$ (Control). These results might be due to promoting effect of combined applied solid and liquid organics on early availability of nutrients in to the soil, resulted higher uptake of nutrient by the crop. These results are corroborating well with the result of Rajanna et al., (2011), Patil et al., (2012) and Laharia et al., (2013) (Table 2).

It is concluded on the basis of results obtained in present investigation, application of
NADAP compost @ $5 \mathrm{tha}^{-1}$ or vermicompost @ $2.5 \mathrm{t} \mathrm{ha}^{-1}$ along with soil application of enriched banana pseudostem sap @ $5 \mathrm{~L} \mathrm{ha}^{-1}$ increased nutrient content and uptake by fenugreek and improved soil properties as well as farmers economy grown under organic farming system in South Gujarat conditions.

\section{References}

Bhunia, S. R., Chauhan, R. P. S., Yadav, B. S. and Bhati, A. S. (2006). Effect of Phosphorus, Irrigation and Rhizobium on Productivity, Water Use and Nutrient Uptake in Fenugreek (Trigonella foenumgraecum L.). Indian Journal Agronomy, 51: 239241.

Boraiah, B., Devakumar, N., Palanna, K. B. and Latha, B. (2015). Influence of composted coir pith, farmyard manure and panchagavya application to capsicum on soil chemical properties. Indian Journal of Agricultural Innovation and Research, 3(5): 23191473.

Choudhary, K. M., Patel, M. M. and Pagar, R.D. (2013). Effect of foliar application of panchagavya and leaf extracts of endemic plants on groundnut (Arachis hypogaea L.). Legume Research, 37(2): 223-226.

Das, N. (2014). Compost (Biodegradable Waste Management Methods) as a means of sustainable agriculture in North-Eastern Region of India. Research Journal of Agriculture and Environmental Management, 3(7): 334-339.

Dekhane, S. S., Khafi, H. R., Raj, A. D. and Parmar R. M. (2011). Effect of biofertilizers and fertility levels on yield, protein content and nutrient uptake of cowpea (Vigna unguiculata L. Walp). Legume Research. 34(1): 
51-54.

Gupta, S. C. (2006). Effect of Combined Inoculation on Nodulation, Nutrient Uptake and Yield of Chickpea in Vertisol. Journal of Indian Society Soil Science, 54: 251-254.

Jat, S. L., Prasad, K. and Parihar, C. M. (2012).Effect of organic manuring on productivity and economics of summer mungbean. Annals of Agricultural Research. 33(1 \&3): 1720.

Khiriya, K. D. and Singh, B. P. (2003). Effect of Phosphorus and Farmyard Manure on Yield, Yield Attributes and Nitrogen, Phosphorus and Potassium Uptake of Fenugreek (Trigonella foenum-graecumL.). Indian Journal of Agronomy, 48: 62-65.

Kumar, A., Kumar, A., Kumar, V., Singh, B., Chauhan, P. and Tripathi, S. K. (2012). Study of different sources for enrichment of compost through NADEP. Society for Recent Development in Agriculture, 12(2): 365-369.

Kumar, D. and Sharma, Y. (2014).Effect of vermicompost and phosphorus on nutrient content, uptake and quality in fenugreek (Trigonella foenumgraecum L.). An Asian Journal of Soil Science, 9(2): 276-279.

Laharia, G. S., Patil, D. U. and Damre, P. K. (2103).Effect of organic sources on fertility, nutrient uptake and yield of soybean. Crop Research, 45(1,2\&3): 155-159.

Naikwade, P. V. (2014) Evaluation of leaf litter compost and vermicompost on yield and nutrient uptake of trigonella. Indian Journal of Applied Research, 4(2): 76- 80.

Naikwade, P. V., Mogle, U. and Jadhav, B. (2011). Comparative study of aerobic and anaerobic composts prepared from autumn leaves on Zea mays L. Science
Research Reporter, 1(2): 77-82.

Patil, D. U., Laharia, G. S. and Damre, P. R. (2012). Effect of different organic sources on biological properties of soil, nutrient uptake, quality and yield of soybean. An Asian J. Soil Sci., 7(2): 190-193.

Patil, T. D. and Kolambe, B. N. (2013). Effect of rates of castor cake and banana pseudostem sap on the nutrient concentration, uptake and yield of organic garlic (Allium sativum L.). An Asian Journal of Soil Science, 8(2): 264-269.

Rajanna, G. A., Murali, K., Gopakalll, P., Divya, M., Lakshmipathy, R. N. and Sudakara, T. M. (2011). Effect of different sources and time of application of organic manures on microbial population, root volume, root dry weight and soil nutrient status of aerobic rice. Environmental and Ecology, 29(3): 260-1264.

Registeri, R., Taghavi, S. M. and Banihashemi, Z. (2012). Effect of Root Colonizing Bacteria on Plant Growth and Fusarium Wilt in Cucumismelo. J. Agr. Sci. Tech., 14: 1121-1131.

Salunkhe, J. R., Patel, A. M., Patil, R. G. and Pisal, R. R. (2013). Effect of banana pseudostem sap as liquid fertilizer in onion. Indian Journal of Agricultural Research, 47(3): 258-262.

Sathish, G. and Paramaguru, P. (2010). Response of bioregulants on nutrient uptake pattern of turmeric (Curcuma longa L.) cv. BSR 2. Madras Agricultural Journal, 97(10-12): 312314.

Singh, Y., Singh, C. S., Singh, T. K. and Singh, J. P. 2006.Effect of Fortified and Unfortified Rice-straw Compost with NPK Fertilizers on Productivity, Nutrient Uptake and Economics of Rice (Oryza sativa). Ind. J. Agron., 
51: 297-300.

Sivaprakashan, K. 1991. Soil Amendment for Crop Disease Management. In: "Basic Research for Crop Disease Management”, (Ed.): Vidyasekharan, P. Day Publishing House, New Delhi, India, PP. 382-404.

Sreenivasa, M. N., Naik N. M. and Bhat, S.N. (2010) Beejamruth: A source for beneficial bacteria. Karnataka Journal of Agricultural science, 17(3): pp.7277.
Tak, S., Sharma, S. K. and Reager, M. L. (2014). Effect of vermicompost and zink on yield attributes, yield and quality of greengram [Vigna radiate Var. aureus (L.) Wilczek] in arid western Rajasthan. International Journal of Agricultural Sciences, 10(1): 138-141.

Tiwari, K.N. (2002). Nutrient Management for Sustainable Agriculture. J. Ind. Soc. Soil Sci., 50: 374-377.

\section{How to cite this article:}

Dhara D. Lunagariya, V.J. Zinzala and Sandip T. Patel. 2019. Effect of Organics on Content and Uptake of Nutrients by Fenugreek (Trigonella foenum-graecum 1.) Grown under Organic Farming System. Int.J.Curr.Microbiol.App.Sci. 8(01): 68-76.

doi: https://doi.org/10.20546/ijcmas.2019.801.009 